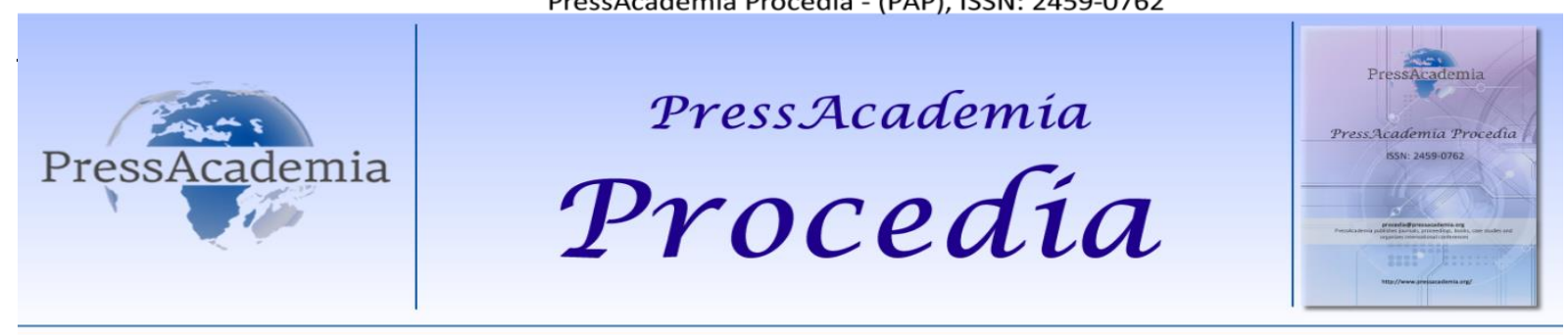

Global Business Research Congress (GBRC), May 24-25, 2017, Istanbul, Turkey.

\title{
APPLICATION OF BENCHMARKING IN LOCAL ADMINISTRATIONS: THE CASE OF NILUFER MUNICIPALITY
}

DOI: 10.17261/Pressacademia.2017.664

PAP-GBRC-V.3-2017(91)-p.841-853

\section{Aysel Çetindere Filiz ${ }^{1}$, Cengiz Duran ${ }^{2}$, Birsen Karaaslan ${ }^{3}$}

${ }^{1}$ Ondokuz Mayıs University, Faculty of Economics and Administrative Sciences, Samsun, 55000, Turkey. aysel.cetindere@omu.edu.tr

${ }^{2}$ Dumlupınar University, Faculty of Economics and Administrative Sciences, Kütahya 43000, Turkey. cduran35@gmail.com

${ }^{3}$ Dumlupınar University, Science Specialist, Kütahya 43000, Turkey.

\section{To cite this document}

Filiz, A.C., C. Duran and B. Karaaslan, (2017). Application of benchmarking in local administrations: the case of Nilufer municipality. PressAcademia Procedia (PAP), V.3, p.841-853.

Permemant link to this document: http://doi.org/10.17261/Pressacademia.2017.664

Copyright: Published by PressAcademia and limited licenced re-use rights only.

\begin{abstract}
Benchmarking is a quality management process which provide the opportunity to businesses, institutions and organizations to develop selfexamining with best practices in the industry. As a driving force benchmarking bring change to managed and thus enabling continuous improvement and quality. In the literature of business administration the notion of benchmarking would be defined as comparison of the services in the field of public management. In the local authorities, a process about feasibility of benchmarking consist four levels and nine steps was produced. This process was sustained through interviews with quality management agents in the municipality according to answer-question technique. At the end of the work, the municipality uses strategic benchmarking according to point of focus, functional benchmarking according to chosen partner since 2003. These works are functioned by including strategic planning process in quality management system.
\end{abstract}

Keywords: Benchmarking, local administrations, quality management system, service sector, service comparison.

JEL Codes: L33

\section{YEREL YÖNETIMLERDE BENCHMARKING UYGULAMASI: NILÜFER BELEDIYESi ÖRNEĞi}

\section{ÖZET}

Benchmarking işletmelere, çeşitli kamu kurum ve kuruluşlarına sektördeki iyi örnekleri inceleyerek kendini geliştirme fırsat sunan bir kalite yönetim sürecidir. Sürükleyici bir güç olan benchmarking, değişimi gerçekleştirip yönetmeyi ve bu sayede sürekli gelişmeyi ve kaliteyi olanaklı kılmaktadır. Işletme literatüründe benchmarking olarak kullanılan bu yönetim süreci kamu yönetiminde genellikle "hizmet karşılaşırması" olarak kullanılmaktadır. Bu çalışmayla yerel yönetimlerde benchmarking yönteminin uygulanabilirliğine yönelik olarak dört aşama ve dokuz adımdan oluşan bir süreç ortaya konulmuştur. Bu süreç, uygulama yapılan belediyede kalite yönetim temsilciliğiyle yapılan görüşmeler yoluyla soru cevap tekniğine göre sürdürülmüştür. Çalışmanın sonucunda belediyede 2003 yılından bu yana, odaklanılan noktaya göre stratejik, seçilen ortağa göre ise fonksiyonel benchmarking türünün kullanıldığı ve bu çalışmaların kalite yönetim sistemi içerisinde stratejik planlama sürecine dahil edilerek yürütüldüğü ifade edilmiştir.

Anahtar Kelimeler: Benchmarking, yerel yönetimler, kalite yönetim sistemi, hizmet sektörü, hizmet karşılaştırması. JEL Kodları: L33 


\section{GiRiş}

Benchmarking (Kıyaslama) bir işletmenin kendi performansını yükseltebilmek için, üstün performansı olan diğer işletmelerin incelenmesi, bu işletmelerin iş yapma usullerini kıyaslaması, bu kıyaslamadan çıkardığı sonuçları uygulaması olarak tanımlanabilir (Bumin ve Erkutlu, 2002: 90). Kıyaslama çalışmaları ile üstün performans standartlarına erişmek için sürekli olarak en iyiyi taklit ederek değişim gerçekleştirilmektedir. Dışarıya odaklanarak gerçekleştirilen uygulamalarla yapılan iyileştirmelerin etkili olup olmadığının belirlenmesinin yanı sıra rekabetçi miyiz sorusuna da yanıt aranmaktadır. Kıyaslama çalışmaları ilk kez 1980'lerin ortalarında Rank Xerox öncülüğünde Japonya'da gerçekleştirilmiştir (Zairi, 1994: 11). Xerox'tan sonra Ford, AT\&T, Motorola ve DuPont gibi pek çok başarılı Amerikan şirketi de uluslararası operasyonlarında iyileştirme çalışmaları için bu yönteme başvurmuştur. Bu başarıı uygulamaların hepsi benchmarking yönteminin karlılığı artırdığını göstermiş ve bu yöntemin gelişip uluslararası işletmeler arasında hızla yayılmasını sağlamıştır (Tektaş ve Tosun, 2010: 31). Literatürde kıyaslama ile ilgili yapılmış farklı tanımlar ve sınıflandırmalar aşağıda ifade edilmiştir.

David Kearns (Xerox şirketi yöneticisi-1980'ler); güçlü rakipler ya da endüstri lideri olarak bilinen firmalara göre ürün, hizmet ve uygulamaların değerlendirildiği sürekli bir süreçtir.

Robert C. Camp (1989); belirli bir etkinlik için üstünlük sağlayacak en iyi uygulamaların araştırılarak iş yapma usullerinin kıyaslanması ve bu kıyaslamalardan çıkarılan sonuçların uygulanmasıdır. Camp kıyaslama türlerini ise: İçsel (işletme içerisinde yapılan dahili kıyaslama), rekabetçi (rakiplerin kıyaslama ortağı seçilmesiyle yapılan kıyaslama), işlevsel (Fonksiyonel; işletmelerin farklı bir endüstri dalından aynı işleve sahip bir başka işletmeyle kıyaslanması) ve jenerik (Süreç) kıyaslaması şeklinde dört farklı sınıflandırmayla ifade etmiştir.

Vaziri (1992); bir organizasyonun performansını, kritik tüketici ihtiyaçlarına göre neyin geliştirilmesi gerektiğini belirleyerek sektördeki en iyi performansla karşılaştıran sürekli bir süreçtir.

Kleine (1994); bir organizasyonun, gelişim sağlamak için belirlediği performans hedefini gerçekleştirmiş olan diğer firmaların uygulamalarını yeniden tasarlayarak kullandığı mükemmel bir araçtır.

Drew'e (1997) göre kıyaslama türleri: Süreç kıyaslaması (işlemlerin, uygulamaların ve işletme süreçlerinin kıyaslanması), ürün/hizmet kıyaslaması (ürün ve/veya hizmet olanaklarının karşılaştııılması), stratejik kıyaslama (organizasyonel yapılar, yönetimsel uygulamalar ve işletme stratejilerinin karşılaştırılması) şeklinde üç sınıfa ayrılmaktadır.

Fong vd.(1998) kıyaslama türlerini tablo 1.'de gösterildiği gibi ifade etmişlerdir.

\section{Tablo 1: Benchmarking Türleri}

\begin{tabular}{|c|c|c|}
\hline Sınıflandırma & Tür & Açıklama \\
\hline Referans alınan noktaya göre & $\begin{array}{l}\text { İçsel } \\
\text { Rekabetçi } \\
\text { Endüstriyel } \\
\text { Jenerik } \\
\text { Global }\end{array}$ & $\begin{array}{l}\text { Bir organizasyon içerisinde benzer iş birimlerinin ya da süreçlerinin } \\
\text { performansının kıyaslanmasıdır. } \\
\text { Doğrudan doğruya rakiplerin genel olarak performans düzeylerine erişmek ya } \\
\text { da bu düzeyi aşmak için yapılan kıyaslamadır. } \\
\text { Aynı endüstri dalındaki organizasyonlarla kıyaslamadır. } \\
\text { Endüstri sınırlarını aşan organizasyonlarla karşılaştırmadır. } \\
\text { Coğrafik olarak ülke sınırlarının ötesindeki organizasyonlarla karşılaştırmadır. }\end{array}$ \\
\hline Kıyaslamanın içeriğine göre & $\begin{array}{l}\text { Süreç } \\
\text { Fonksiyonel } \\
\text { Performans } \\
\text { Stratejik }\end{array}$ & $\begin{array}{l}\text { İş süreçleriyle ilgili kıyaslama yapılır. } \\
\text { İki veya daha fazla organizasyonda belli işletme fonksiyonlarının } \\
\text { karşılaştırıldığı süreç kıyaslamasının uygulanmasıdır. } \\
\text { Fiyat, hız, güvenilirlik gibi ölçülebilir çıktılarla ilgili yapılan kıyaslamadır. } \\
\text { Operasyonel konulardan ziyade stratejik değerlendirmeleri içerir. }\end{array}$ \\
\hline İlişkilerin amacına göre & $\begin{array}{l}\text { Rekabetçi } \\
\text { İşbirlikçi }\end{array}$ & $\begin{array}{l}\text { Rakiplerden de fazla olması beklenen üstünlüğü sağlamak için yapılan } \\
\text { karşılaştırmadır. } \\
\text { Bilginin paylaşımını ve öğrenme atmosferini geliştirmek için yapılan } \\
\text { karşılaştırmadır. }\end{array}$ \\
\hline
\end{tabular}

Kaynak: Fong vd., 1998: 410.

Bumin ve Erkutlu’ya (2002) göre kıyaslama türlerini sınıflandırırken işletmenin hareket noktası dikkate alındığında genelde iki farklı sınıflandırma olanağı görülmektedir (Bumin ve Erkutlu, 2002: 91-92);

1. İşletmenin odaklandığı noktaya göre kıyaslama türleri

- Ürüne odaklı kıyaslama; başka bir işletmenin ürününü parçalara ayırıp ya da bütün olarak detaylı bir biçimde incelemeyi içerir. 
- Sürece odaklı kıyaslama; faaliyetlerin bütünsel bir bakışla yeniden gözden geçirilmesini kapsamaktadır.

- Stratejilere odaklı kıyaslama; farklı işletme stratejilerinin karşılaştırılmasıdır.

2. İşletmenin seçtiği ortağa göre kıyaslama türleri;

- İçsel kıyaslama; aynı işletmenin kendi içerisinde veya bir holdingin bünyesindeki farklı işletmeler arasında kıyaslama yapilır.

- Rekabetçi kıyaslama; rakibin hangi yönden ve neden üstün olduğu araştırılıp elde edilen sonuçlar işletmenin yapısına uygun olarak uyumlaştırılıp performans artışı sağlanır.

- Sektör dışı kıyaslama; farklı bir sektörden lider bir işletmenin kıyaslama ortağı olarak seçildiği kıyaslama türüdür.

- Türünün en iyisi uygulamaları; burada kıyaslama ortağı "en iyi" tek bir işletme değil, daha çok sektörlerinin en iyisi olan pek çok işletmenin bileşimidir.

Watson (2007) kıyaslama türlerini süreç kıyaslaması (stratejik ya da operasyonel olarak iki farklı şekilde gerçekleştirilmektedir) ve veri kaynaklarına göre kıyaslamalar olmak üzere iki genel kategori düzeyinde ele almıştır. Stratejik kıyaslamada amaç bir organizasyonun diğer organizasyonlara göre rekabet avantajını arttırmak ve ilerlemeye neden olacak değişimler için fikir geliştirmektir. Bir işletmenin rekabet avantajını sürdürmesi ya da önemli değişimleri gerçekleştirebilmesi için kritik iş alanlarına odaklanılması konularında kıyaslama yapılmaktadır. Örneğin işletmenin yönetim yapısı, yatırım kararları, araştırma-geliştirme çalışmalarına yapılan yatııılar, hem ürün hattı hem de işletmeyle ilgili yönetim tercihlerini etkileyen kararlar, ISO 9000, toplam kalite yönetimi gibi ya da 6 sigma gibi bir organizasyonun yapısını tümüyle değiştirebilecek uygulamalar stratejik kıyaslamaya örnek olarak verilebilir. Operasyonel kıyaslama faaliyetleri ile üretim, satış ve dağııım gibi operasyonel süreçlerde performansın iyileştirilmesi amaçlanır. Rutin işletme faaliyetlerinde belirli iş alanlarına odaklanarak bu alanlarda etkililik, etkinlik ya da ekonomiklik yönünden iyileştirmelerle verimlilik artışları sağlanır. Üretim metotlarının değerlendirilerek en düşük maliyet, en az hata, bitmiş ürün envanterinin en az düzeyde olduğu ve ürün/hizmetin en hızlı şekilde ulaşımının sağlandığı en verimli sürecin belirlenmesiyle ilgili yapılacak olan uygulamalar örnek olarak verilebilir (Watson, 2007: 6-8).

Watson (2007) veri kaynaklarına göre yapığı sınıflandırmada ise; 1.Rekabetçi kıyaslama (genellikle aynı endüstrilerde ve pazarlarda rekabet eden organizasyonlarda özel ürün tasarımları, süreç yeterliliği ya da sadece rakiplerin kullandığı yönetimsel metotların kıyaslaması yapılır); 2.Fonksiyonel kıyaslama (fonksiyonel alana odaklı bir şekilde aynı iş sürecinde olabildiği gibi aynı yada farklı endüstrilerde de gerçekleştirilebilen bir kıyaslama türüdür); 3.iççel kıyaslama (organizasyondaki aynı iş süreci ya da işletme fonksiyonu için performans kıyaslaması yapılır); 4.Jenerik kıyaslama (farklı bir endüstri dalındaki işletmenin süreçleriyle ilgili performansı değerlendirilir. Örneğin bir otomobil üreticisinin dağıtım faaliyetlerini nasıl kontrol ettiği ile ilgili bilgilerden hareketle gıda tedarikçilerinin dağıtım faaliyetlerini karşılaştırması bu kıyaslamaya örnek verilebilir) şeklinde kıyaslamaların yapılabileceğini ifade etmiştir.

Stratejik ya da operasyonel düzeyde gerçekleştirilen kıyaslama uygulamalarında kullanılan farklı veri kaynaklarıyla ilgili bilgiler tablo 2.'de gösterildiği gibidir.

Tablo 2: Kıyaslama Verilerinin Kaynağına göre Kıyaslama Türlerinin Karşılaştırılması

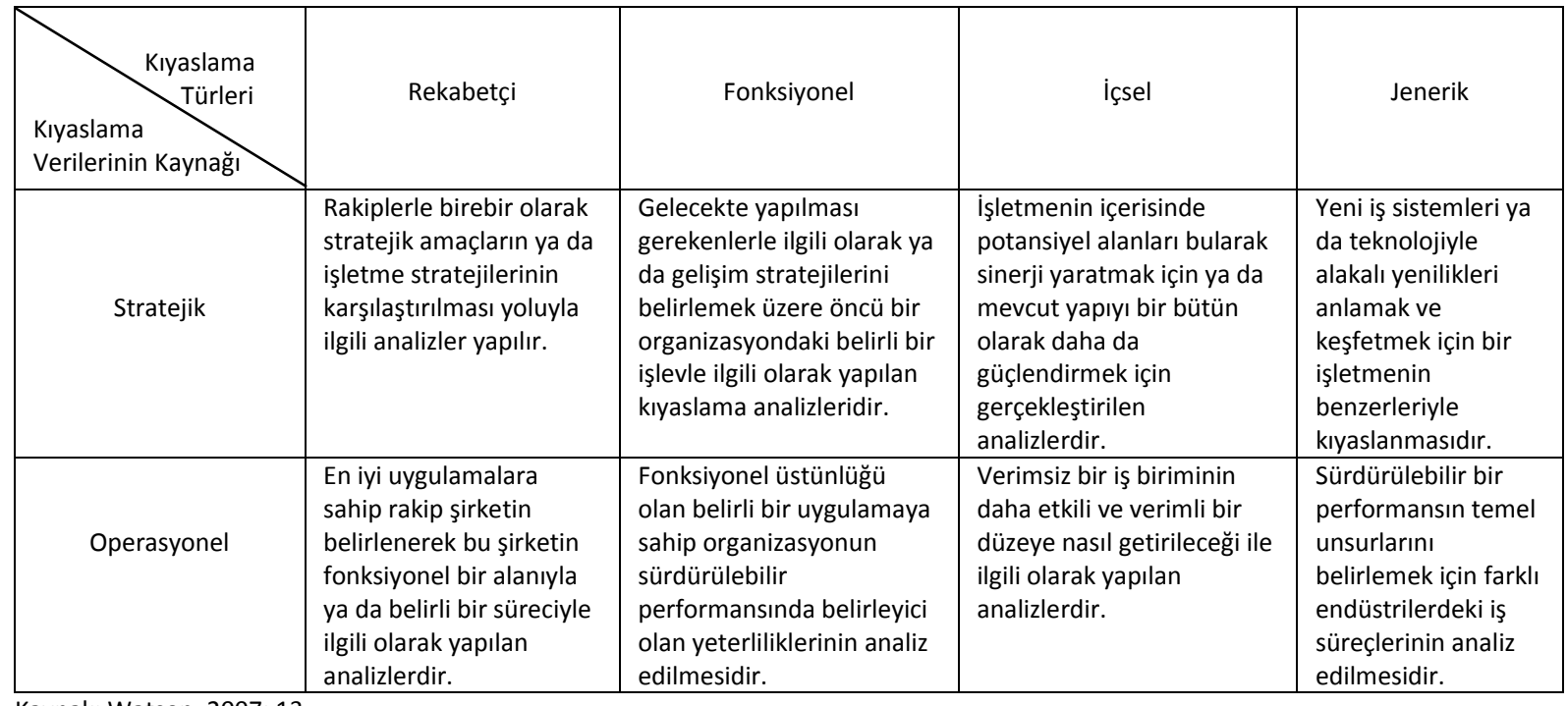

Kaynak: Watson, 2007: 13 
Temel yaklaşımı itibariyle kıyaslama, bir işletmenin, sürekli olarak ve bilinçli bir biçimde, kendi dallarında ve sektörlerinde en iyi (başarılı) olan işletmelerin belirli işleri nasıl yaptıklarını araştırması, analiz etmesi, kendi usulleri ile karşılaştırarak sonuçlar çıkarması, çıkardıkları bu sonuçları bir plan dahilinde uygulayarak daha yüksek bir başarı düzeyini yakalamaya çalışması çabaları olarak da ifade edilebilir (Bumin ve Erkutlu, 2002: 90). Ürünlerin ve süreçlerin sürekli bir biçimde en iyi uygulamalarla kıyaslanması sonucunda iş performansının nasıl iyileştirileceği belirlenmiş olmaktadır. Kıyaslama yönteminde başarılı işletmelerin taklit ediliyor gibi görünmesine karşın işletmeleri yeni arayışlara sürüklemesi nedeniyle de inovatif iş fikirlerinin doğmasına yol açmaktadır.

Potansiyel kıyaslama ortaklıkları, aynı organizasyonun farklı birimlerinde, aynı veya farklı coğrafi pazarlara sahip rakiplerle ya da farklı sektörlerdeki firmalarla kurulabilmektedir. Organizasyonlar için birden fazla kıyaslama konusu olabilmektedir. Örneğin Procter\&Gamble; pazarlama yönetimi, 3M; takım çalışması, inovasyon ve yeni ürün geliştirme, Disney; eğlence, topluluk yönetimi, Toyota; tam zamanında üretim, Motorola; kalite yönetimi, sürekli geliştirme, Hewlett-Packard; sürekli inovasyon, Wal-Mart; lojistik, bilgi teknolojileri kullanımı, General Electric; iş sürecinin yeniden tasarımı, liderlik geliştirme, stratejik planlama, Banc One Corporation; kazanç stratejisi, mali varlıkların getirisiyle ilgili performans düzeyi, maliyet kontrolü, L. L. Bean; posta ile sipariş süreçleri, lojistik faaliyetleri, McDonalds; Franchising ve hizmet tutarlılığı ile ilgili kıyaslama yapılan çalışma konuları kapsamında örnek alınan firmalardır (Drew, 1997: 428-429).

\section{LITERATÜRDE YER ALAN BENCHMARKING MODELLERI}

Kıyaslama ile ilgili olarak literatürde yer alan uygulamalarda süreçler farklı modeller ile ifade edilmiştir.

Robert C. Camp’a (1993) göre kıyaslama süreci planlama, analiz, bütünleştirme ve eylem olmak üzere dört aşamadan oluşmaktadır.

Jetmarová (2011) kıyaslama çevrimi olarak ifade ettiği sürecin planlama, veri toplama, verilerin analiz edilmesi ve uyarlama olmak üzere kıyaslama çevrimi olarak belirttiği 4 aşamadan oluştuğunu ifade etmiştir. Bu aşamalar ve aralarındaki ilişkiler şekil 1.'de gösterildiği gibidir. Şeklin sol kısmında işletme içerisinde nelerin olduğu ile ilgili bilgiler yer alırken sağ kısmında rakip işletmelerdeki en iyi uygulamalarla ilgili bilgiler yer almaktadır.

\section{Şekil 1: Kıyaslama Çevrimi}

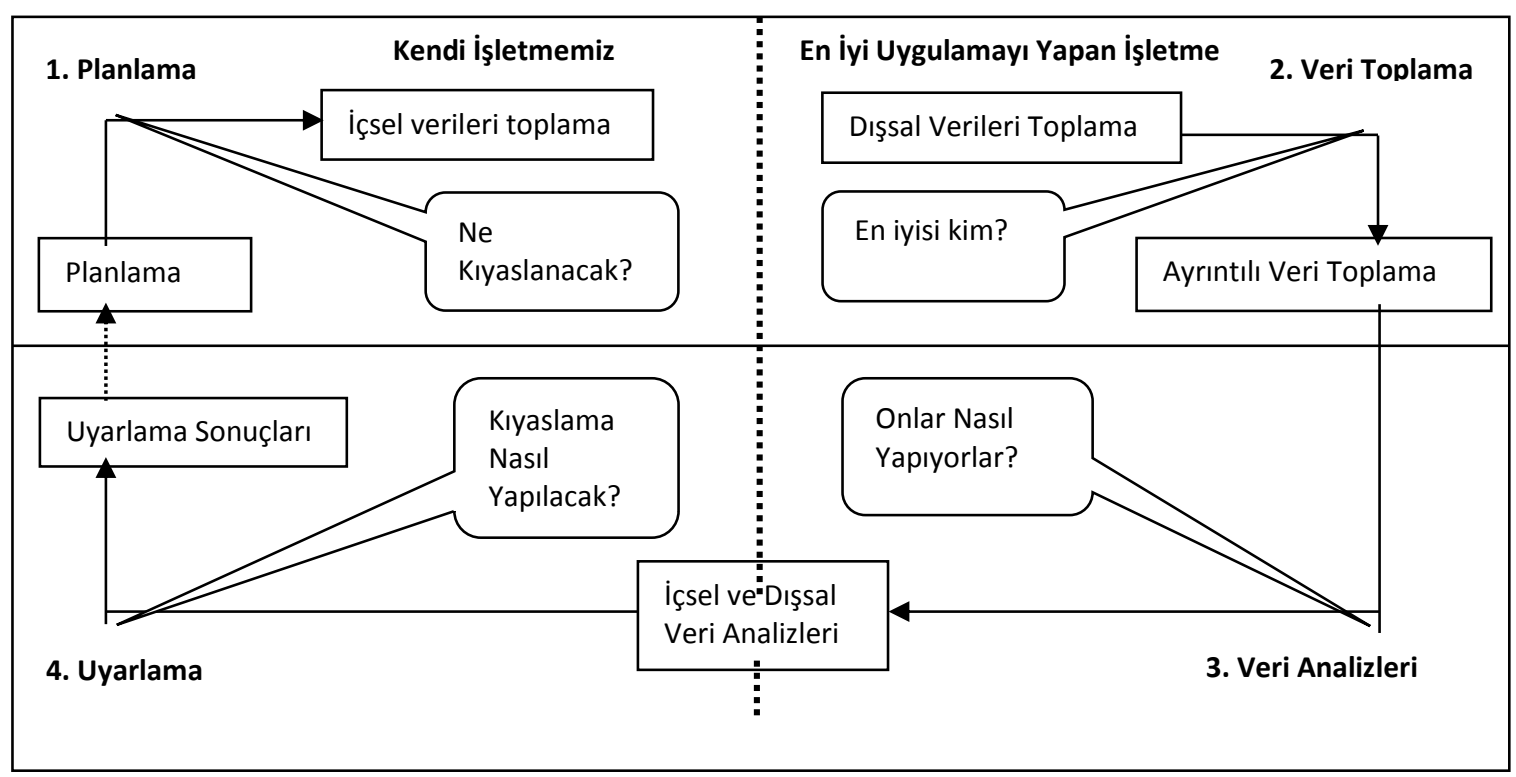

Planlama aşamasında amaçların neler olduğu belirlenir. Verilerin toplanması aşamasında iç ve dış verilerin toplanması, kıyaslama ortağının belirlenerek detaylı verilerin sağlanması, diğer kaynaklardan ortaklar ile ilgili bilgilerin toplanması sağlanır. Analiz aşamasında verilerin tasnif edilerek organize edilip düzenlenmesi ve bilgiye dönüşümünün sağlanması amaçlanır. Böylece gelişim sağlanacak süreçler belirlenerek bu süreçlerdeki değişim için yeni amaçlar belirlenir. Uyarlama aşamasında en iyi uygulama örnekleri esas alınarak mevcut planlar ile yeni planlar birleştirilerek güncel planlar oluşturulur (Jetmarová, 2011: 81). 
Fong vd. (1998) ise kıyaslamayı müşteri istek ve ihtiyaçlarının karşılanarak müşteri memnuniyetinin sağlandığı performansı arttıran sistematik bir yaklaşım olarak değerlendirmiştir. Planlama, analiz, bütünleştirme, eylem ve olgunluk aşamalarını içeren bu yaklaşım şekil 2.'de gösterildiği gibi on adımdan oluşmaktadır.

\section{Şekil 2: Kıyaslama Süreci Modeli}

Ihtiyaçları Değerlendirme Ekibi Müşterilerin belirlenmesi

Temel müşteri intiyaçlarının belirlenmesi

Kıyaslama Ekibi

1. Kıyaslanacakların belirlenmesi

2. Karşılaştırma yapmak için en iyi performansa sahip olanların belirlenmesi

3. Veri toplama yönteminin belirlenmesi ve veri toplama

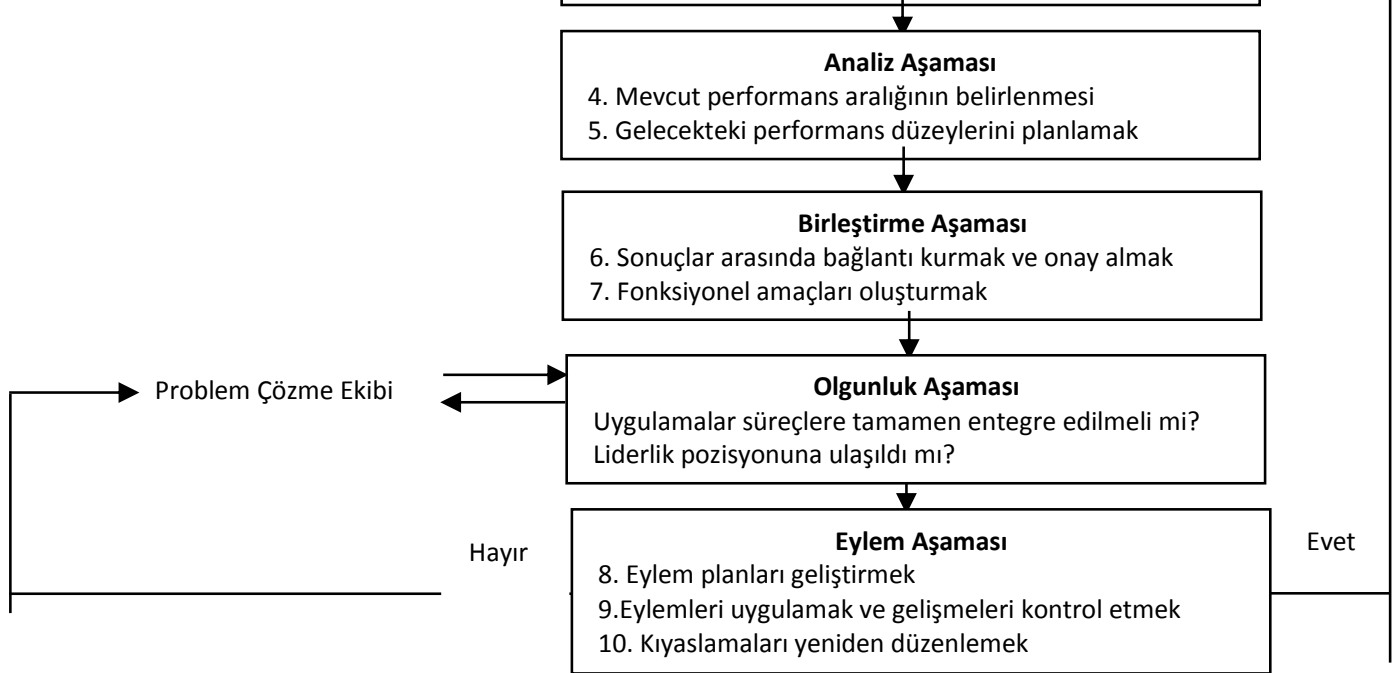

Zairi (1994) başarılı benchmarking uygulamalarında iki önemli aşamanın olduğunu ifade etmiştir. Birinci aşamada önemli dışsal karşılaştırmalar yapmak için içsel bir hazırlık yapabilmek adına içsel süreçlerin etkin bir şekilde yönetilmesi ve kontrol edilmesi yer almaktadır. Etkinlik aşaması olarak ifade edilen bu aşama yedi adımdan oluşmaktadır. İkinci aşamada ise kıyaslama uygulamalarıyla içsel standartları etkili bir şekilde rekabetçi bir yapıya dönüştürmek için dokuz adımdan oluşan bir süreç izlenmektedir. Birinci ve ikinci aşamalarda ifade edilen toplam on altı adım aşağıda belirtildiği gibidir (Zairi, 1994: 2123);

- Temel grafiksel teknikleri kullanarak içsel süreçleri değerlendirmek

- Mevcut performansı niceliksel olarak değerlendirmek

- Gelişim sağlamak için ölçümler yoluyla süreç kısıtlarını ve gelişim fırsatlarını belirlemek

- Kısıtları değerlendirerek süreç geliştirmek

- Ölçüm ve değerlendirmeler yapmak

- İçsel standartlar belirlemek

- Performansın tekrarlanabilir ve tutarlı olmasını sağlamak için etkili standartlar yoluyla kontrol ve süreç yönetiminin yapılması

- Kıyaslama için uygun bir süreç seçmek

- Uygun ortakların belirlenmesi

- Ölçüm stratejilerinin kararlaştırılması

- Standartları karşılaştırmak

- Performans farklılıklarının sebeplerini araştırmak

- Performansı arttırmak için ilgili uygulamaları geliştirmek

- Standartları karşılaştırmak

- Aynı ya da yeni ortaklarla düzenli bir şekilde uygulamaları tekrarlamak

- Müşteriye değer sağlayacak tüm süreçleri kıyaslamak 


\section{YEREL YÖNETIMLERDE KIYASLAMA SÜRECININ UYGULANABILIRLIĞi}

Belediyeler, hizmetleri çeşitlilik gösteren kuruluşlardır. Bu çeşitlilik, bulundukları yörenin koşullarına göre değişiklik göstermektedir. Kalkınmaya ve şehirleşmeye bağlı olarak halkın belediyelerden beklentileri de artmakta ve çeşitlenmektedir. Belediyelerimizin; mali kaynak yetersizliği, nitelikli eleman yetersizliği, merkezi yönetim ile yetki karmaşası, nüfus artışındaki yüksek hız, görev fazlalığı, yeterince şeffaf olamama ve halkın bilinçli olarak belediye hizmetleri konusunda inisiyatif kullanmıyor olması gibi nedenlerle kalite standartlarını yeteri kadar sağlayamadıkları kabul edilmesi gereken bir gerçektir (Demirel vd., 2013: 32).

Belediyeler, toplumsal sorumluluk gereği, toplumsal dinamizme ayak uydurmak zorunda olan kurumlardır. Bir özel sektör mantığıyla hareket etmek durumunda olan belediyeler, gelişen ve değişen ihtiyaçlara bağı olarak, insanların taleplerine cevap verebilmesi için gelişim ve değişim içinde olmak zorundadır. Vatandaş, bir belediye için müşteridir ve müşteri odaklılık anlayışı içinde, vatandaşın taleplerini, beklentilerini ve ihtiyaçlarını, maksimum ölçüde karşılamak ve onları memnun etmek zorunluluğu vardır (Bayraktar ve Yıldız, 2007: 281-282).

Yerel hizmetlerin kullanıcılarının gözünde, sunulan hizmetin kalitesi ve hizmeti sunan birimin performansının belirlenmesi bu sürecin en önemli aşamasıdır. Çünkü ilgili alandaki performans açığını belirlemedeki en etkin yol hizmetin varlık amacı olan kullanıcıların değerlendirmeleridir. Yerel hizmetleri kullananların birer müşteri olarak algılanarak onların memnuniyetinin hizmetlerin devamı ve gelişimi için en temel değer olduğu gerçeğinden hareketle onların tercihlerini belirleyecek çalışmalar yapılmalıdır. Sosyal hakların iyileşmesi ve ekonomik refahın artmasıyla halkın talep ve beklentileri artmıştır. Nasıl ki özel sektör bu gelişmelere duyarsız kalmayarak yenilikçi (innovative) yöntemlerle hazırlanmış performans yönetim modelleri yardımıyla ürün kalitesini artırdıysa, aynen kumu hizmeti sunan yerel yönetimlerde artan talep ve beklentilere yönelik kalite artırımına gitmek zorunda kalmıştır (Demirkaya, 2008: 171-172).

Benchmarking hem özel hem de kamu sektöründe maliyet, verimlilik ve çıktılarla ilgili performans ölçütlerini süreçlerle karşılaştırmada kullanılmaktadır. Son yıllarda pek çok ülkede kamu sektöründe benchmarking uygulamalarında önemli artışlar görülmektedir. İngiltere 1990'ların sonundan itibaren yerel yönetim birimleri ve sağlık kuruluşlarının performans düzeylerini geliştirmek için benchmarking uygulamalarına önemli ölçüde yer vermektedir (Siverbo, 2014: 122).

Kamu sektöründe "benchmarking"i önemli bir araç haline getiren, öğrenme ve karşılaştırma gibi iki önemli unsuru bünyesinde barındırmasıdır. Karşılaştırma süreci, öğrenen organizasyonun sistemli gelişmesini içine alan daha kapsamlı bir modelin tamamlayıcı parçasıdır. Karşılaştırma temelde, bir kurumun sürekli ve bilinçli bir biçimde kendi hizmet alanında en başarılı olan kurumun belli faaliyetleri nasıl yaptığını araştırması kendi metotlarıyla karşılaştırarak sonuç çıkarması, çıkardığı bu sonuca göre bir uygulama planı geliştirerek daha yüksek bir başarı düzeyine ulaşma çabalarını anlatmaktadır (Eren, 2002: 63). Kamu sektöründeki benchmarking çalışmalarının olumlu sonuçları şunlar olabilir (Ensari, 2004: 80):

- Harcamalar arasında ihtiyaca göre eleme yapılması

- Artan verimlilik

- Daha etkili çalışma yöntemleri

- Iletişim becerilerinin artması

- Hızlandırılmış değişme süreçleri

- Artan müşteri ve iş gören tatmini

Kamu sektöründeki benchmarking de tıpkı özel girişimdeki benchmarking gibi aynı aşamaları takip eder. Önce bir teşhise dayalı aşama, daha sonra süreç kıyaslama için bütünsel aşama. Ancak kamu sektöründeki bir örgütün amacı, özel sektördeki bir örgütünkinden farklı olabilir. Bu nedenle maliyet, müşteri sorumluluğu ve hizmet kalitesi vb. ile ilgili uygun göstergelerin seçilmesi gerekir. Bunu yaparken en uygun yaklaşım, kamu örgütü tarafından sunulan hizmetin kullanıcılarını da bu sürece katmaktır (Ensari, 2004: 80).

Literatürde kamu hizmetlerinin karşılaştırma süreci için oldukça çeşitli modeller bulunmakla birlikte bunlar arasında önemli farklılıklar bulunmamaktadır. Şekil 3.'de görüldüğü üzere karşılaştırma süreci üç temel safhaya ayrılmaktadır. Bu safhalar hazırlık, analiz ve uygulama safhalarıdır. Bu safhaların her birisi de kendi içerisinde dört bölüme ayrılmaktadır (Eren, 2002: 71). 
Şekil 3: Kamu Sektöründe Hizmet Karşılaştırma Süreci

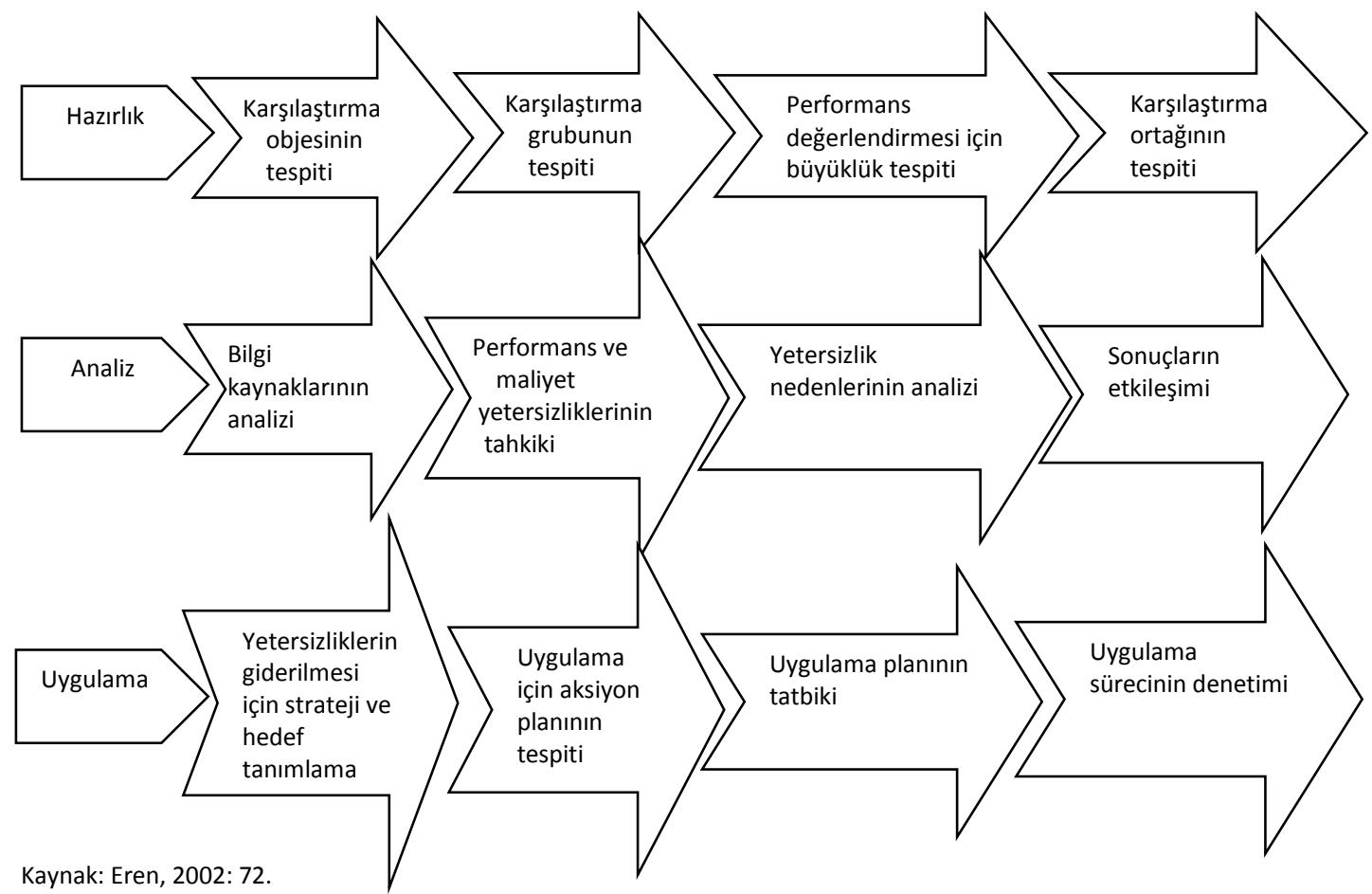

\subsection{Yerel Yönetimler için Benchmarking Uygulama Sürecine ilişkin Model Önerisi}

Nilüfer Belediyesi; "Benchmarking" çalıșmasını 2012-2014 Stratejik planında yer alan kurumsal gelişim amacı kapsamında "kurum çalışanlarının, kaynakların ve süreçlerin iyi bir liderlikle yönlendirilerek daha yüksek paydaş memnuniyetine ve daha başarılı kurumsal performansa ulaşmak" amacı altındaki "mükemmellik modeline göre kurumsal performansı artırmak" hedefi için belirlediği stratejiler kapsamında gerçekleştirmektedir. Bu stratejiler aşağıda ifade edildiği gibidir (www.nilufer.bel.tr/i/pdf/4.pdf);

- Mükemmellik modeline göre kurum öz değerlendirmesi yapılacaktır.

- Yurtdışında tanınırlığı desteklemek ve dış uzmanların değerlendirme yapmasını sağlamak amacı ile Avrupa Kalite Ödülü'ne katılım sağlanacaktır.

- İyi uygulama örnekleri öğrenmek, kıyaslama çalışmaları yapmak ve yeni projeler üretmek için üyelik ve işbirlikleri geliştirilecek ve sürdürülecektir (EFQM, Eurocities, TUSENET, URBACT vb.).

- Belediyeye Ar-Ge çalışmalarını destekleyecek, öğrenme ve kıyaslama fırsatı sağlayacak kitap ve süreli yayınlar kazandırılacaktır.

Bu nedenle belediyenin "benchmarking" çalışmasını stratejik planlama sürecine dahil ederek yürüttüğü anlaşılmaktadır. Bu kapsamda belediye stratejik amaç ve hedeflere yönelik olarak yapılanların raporlanması ve paydaş değerlendirmelerine sunulmasında aşağıdaki yöntemleri kullanmaktadır;

- Yönetim Sistemleri süreç performans göstergelerinin takibi - Sürekli

- Müdürler toplantısı - Ayda 1

- Yönetim Gözden Geçirme Toplantısı - 3 ayda 1

- Muhtar toplantıları - Ayda 1

- Paydaş toplantıları -6 ayda 1

- Proje planı ve proje izleme formları

Nilüfer belediyesi tarafından yürütülen benchmarking çalışmasında belediyenin kalite yönetim temsilcisiyle ve kıyaslama süreç sorumlusuyla e-mail ve telefonla iletişime geçilerek sistem hakkında bilgi alınmıştır. Bu bilgiler doğrultusunda literatür araştırmaları kapsamında yerel yönetimlerde kullanılmak üzere aşağıda belirtilen dört aşama ve toplam dokuz adımdan oluşan bir süreç uygulanabilir. 


\section{Planlama Aşaması}

- Kıyaslama sürecinin belirlenmesi

- Kıyaslama konusunun belirlenmesi

- Kıyaslama ekibinin oluşturulması

- Kıyaslama ortağının belirlenmesi

2. Analiz Aşaması

- Veri toplama metodunun belirlenmesi

- Verilerin toplanması ve analizi

3.Uygulama Aşaması

- Hedeflerin belirlenmesi, eylem planı geliştirme ve uygulama

- Süreçlerin izlenmesi ve kontrol

4. Olgunluk Aşaması

- Sürecin yeniden düzenlenmesi

Yukarıda ifade edilen aşamalar ve adımlar kapsamında kıyaslama çalışmalarını başlatmak üzere belediyeye yöneltilen sorular ve verilen cevaplar aşağıda sıralandığı gibidir;

\section{Kıyaslama çalışması yapmaya ne zaman karar verildi?}

Kıyaslama çalışmaları EFQM Mükemmellik Modelinin bir gereği olarak 2003 yılından beri sürdürülmektedir. Stratejik planda yer alan "'iyi uygulama örnekleri öğrenmek, kıyaslama çalışmaları yapmak ve yeni projeler üretmek için üyelik ve işbirlikleri geliştirilecek ve sürdürülecektir" stratejik hedefi kapsamında kıyaslama faaliyetlerine devam edilmektedir. Kıyaslama çalışmaları Stratejik Yönetim süreci altında yer alan kıyaslama alt sürecine göre gerçekleştirilmektedir.

\section{Kıyaslama çalışmaları için bir çalışma ekibi oluşturuldu mu?}

Kıyaslama çalışmaları Strateji Geliştirme Müdürlüğü'nün koordinasyonunda kıyaslama konusuna göre ilgili birimlerin katılımıyla gerçekleştirilmektedir. Her bir kıyaslama çalışmasında konunun içeriğine göre çalışma ekibi oluşturulmaktadır.

\section{Kıyaslama ortağı nasıl belirlendi?}

Kıyaslama ortaklarının belirlenmesinde mükemmellik modelini uygulayan, modelin uygulanmasında uluslararası ve ulusal alanda başarı sağlamış ve iyi uygulamaları olan kurumlar belirlenmektedir. Bunun için kıyaslama alt süreci dokümanlarında tanımlanan kriterler dikkate alınmaktadır.

\section{Kıyaslama gezileri yapıldı mı? Yapıldıysa bu gezilerin kapsamı, süresi ve yöntemi nasıl belirlendi?}

Çeşitli konularda yapılan geziler olmuştur. Örneğin; Bilim ilaç, Bosch, Bursagaz, Eskişehir Kadın Doğum ve Çocuk Hastalıkları Hastanesi, Tarsus Belediyesi, Şanlıurfa Belediyesi gibi kurumlara kıyaslama gezileri yapılmıştır. Her bir kıyaslama ziyaretinin süresi konusuna göre farklılık göstermektedir. Kıyaslama konuları mükemmellik modeli uygulamaları ve kriterlerine göre belirlenmektedir. Strateji, liderlik, çalışanlar, yetenek yönetimi, algı ölçümleri ve Avrupa Kalite Ödülü başvurusu ve saha ziyareti hazırlıkları gibi konularda kıyaslama ziyaretleri düzenlenmiştir. Örneğin Tarsus Belediyesi ziyaretinde kıyaslama konusu süreçler, sosyal yardım, insan kaynakları, gibi konular olmuştur. Tarsus Belediyesinde süreçlerin izlenmesinde yararlanılan portal uygulamasından etkilenilmiştir ve bu ziyaret sonrasında süreçlerin izlenmesi için QPR-Süreç Yönetim Sistemi Portalı satın alınmıştır. Bu portal üzerinden süreç haritalarının akış diyagramlarına, süreç performans-stratejik plan performans ve temel performans göstergelerine ulaşılabilmekte ve takibi sağlanmaktadır. Göstergelerin takibiyle QPR Portalı üzerinden güncel bilgilere ulaşma ve yıllar bazında eğilimleri görebilme gibi konularda ciddi destekler sağlanmaktadır. Ayrıca vatandaş algıları ve performans sonuçları, çalışan algıları ve performans göstergeleri ve iş sonuçlarından bazıları (gelirin gidere oranı, stratejik hedeflerin gerçekleşme oranı, tahsil edilen verginin tahakkuk edilen vergiye oranı gibi) konularda da karşılaştırmalar yapılmıştır.

Bosch ziyaretinde kıyaslama konusu stratejik yönetim süreci ve yetkilendirilmiş çalışanlar konusunda olmuştur. Herhangi bir veri karşılaştırması yapılmamıştır. Bu ziyaretten sonra Bosch'un stratejik yönetim sürecinde dış çevre analizi kapsamında uyguladığı bir stratejinin başarılı olup olamama ihtimallerini belirlemede çevresel faktörlerden yararlanarak bir çerçeve oluşturmak için kullandıkları PESTEL Analizi (Political (politik), Economic(Ekonomik), Social(Sosyal), Technological(Teknolojik), Environmental(Çevresel) ve Legal(Yasal)) uygulanmaya başlanmıştır. Bu analizler ile politik, ekonomik, yasal ve yönetimsel uyumluluk alanlarındaki mevcut ve oluşabilecek olumlu ve olumsuz etkiler de analiz edilerek 
kısa (Yıllık performans programı/Fonksiyonel stratejik plan), orta (Stratejik plan revizyonu) ve uzun dönem (5 yıllık Stratejik Plan) planlamalara yansıtılmaktadır.

\section{Kıyaslama yapılacak alanlar nasıl belirlendi? Bu alanlarda ne kadar iyileştirme sağlandı?}

Kıyaslama yapılacak alanlar öz değerlendirme ve ödül başvuru geribildirim raporlarından hareketle iyileştirmeye açık alan olarak belirlenen konular için belirlenmiştir. Bu alanlarda iyileştirme sağlanıp sağlanmadığı konuyla ilişkili performans göstergeleri ile sonraki öz değerlendirme ve geri bildirim raporları izlenmektedir.

\subsubsection{Planlama Aşaması}

Benchmarking yapma ihtiyacı, iç ve dış çevrenin analiz edilmesi sırasında, işletme performansına ilişkin göstergelerin izlenmesi aşamasında veya işletmede yeni bir uygulamanın (yeni üretim/servis yöntemleri, yeni yönetim yaklaşımları vb.) başlatılması esnasında ortaya çıkabilmektedir. Bu nedenle, söz konusu ihtiyaç öncelikle işletmenin üst yönetimi tarafından net bir şekilde ortaya konulmalıdır (Seymen ve Bolat, 2002: 228). Planlama aşamasının ilk adımı kıyaslama sürecinin belirlenebilmesidir ve bu durumda aşağıda ifade edilen sorulara cevap arayarak benchmarking çalışmasını başlatmak mümkündür (Bedük, 2002: 36):

\section{Soru 1: Neleri Karşılaştıralım?}

"5393 sayılı Belediye Kanunu ve 5216 sayılı Büyükşehir Belediyesi Kanunu” incelendiğinde yerel yönetimlerin görev ve yetkilerinin oldukça geniş olduğu görülmektedir. Burada hizmet kalitesini ölçen önemli göstergelerden birisi vatandaşın memnuniyet derecesidir. Bu aşamada yerel yönetimler; yönetim süreci, insan kaynaklarının etkinliği, bilgi işlem teknolojileri, altyapı hizmetleri, vatandaş memnuniyeti, kentsel dönüşüm gibi konular ele alınabilir. Hizmet sahasındaki vatandaşın şikayet, öneri ve beklentileri mutlaka dikkate alınmalı özellikle halkla ilişkiler gibi doğrudan vatandaşla diyalog halinde olan kurum personeli de sürece dahil edilmelidir.

\section{Soru: Biz Nasıl Yapıyoruz?}

Kendi sürecimizi, yöntemlerimizi sistematik bir şekilde belgelemek ve akış diyagramlarını çizmek başarı için önemlidir. (Örneğin çıktılar nedir/nasıl ölçülür, müşteri kimdir/istekleri nedir ve bu istekler sürece nasıl yansır, sürecin giderleri nelerdir, kimler girdi sağlar, sürecin sahibi ve sınırları nelerdir, sürecin başarısı nasıl ölçülür) (Bedük, 2002: 37).

\section{En iyi kim?}

Seçtiğimiz konuda en iyi uygulamanın nerede olduğu araştırılmalıdır. Başarıı olarak bilinen kuruluşların süreçleri ziyaretlerle incelenebileceği gibi dergi ve konferanslar da takip edilerek uzmanlık alanlarına göre doğru organizasyon, kurum veya kuruluş tespit edilebilir.

\section{Onlar nasıl yapıyor?}

Halka açık seminerler, bildiriler, şirketlerin yayınları, mektup ve telefonla anket doğrudan gözlemleme (Bedük, 2002: 37), başka hizmetlerin incelenmesi gibi yöntemler bilgi sağlama yöntemi olarak belirlenebilir.

Planlama aşamasının ikinci adımı kıyaslama konusunun belirlenmesidir. Hangi konularda kıyaslama yapılacağının ortaya konulması gerekir. Planlama aşamasında aşağıda belirtilen hususların yerine getirilmesi kıyaslama için ayrılacak kaynakların belirlenmesine katkı sağlayacaktır (Kocabaş, 2004: 5-6; Topaloğlu ve Kaya, 2008: 40; Bedük, 2002: 38):

- Kuruluşun amaç ve hedeflerini belirlemek; örneğin işletme rakiplerini göz önüne alarak uzun vadede lider olma hedefi belirleyebilir ve bu hedefe ulaşabilmek için liderlik hedefini stratejik amaç olarak saptayabilir.

5018 sayılı Kamu Mali Yönetim ve Kontrol Kanununun "stratejik Planlama ve Performans Esaslı Bütçeleme" başıklı 9. Maddesine göre (www.mevzuat.gov.tr);

"Kamu idareleri; kalkınma planları, programlar, ilgili mevzuat ve benimsedikleri temel ilkeler çerçevesinde geleceğe ilişkin misyon ve vizyonlarını oluşturmak, stratejik amaçlar ve ölçülebilir hedefler saptamak, performanslarını önceden belirlenmiş olan göstergeler doğrultusunda ölçmek ve bu sürecin izleme ve değerlendirmesini yapmak amacıyla katılımcı yöntemlerle stratejik plan hazırlarlar".

"Kamu idareleri, kamu hizmetlerinin istenilen düzeyde ve kalitede sunulabilmesi için bütçeleri ile program ve proje bazında kaynak tahsislerini; stratejik planlarına, yıllık amaç ve hedefleri ile performans göstergelerine dayandırmak zorundadırlar".

- Süreçlerden kıyaslama için uygun ve öncelikli olanları belirlemek

- Sürecin girdilerini, aşamalarını ve çıktılarını belirlemek

- Kritik başarı faktörlerini belirlemek (örneğin müşteri tatmini)

- En çok probleme yol açan faktörlerin belirlenmesi 
- Müşteriye sunulan ürün ve hizmetlerin neler olduğunun belirlenmesi

- Kurum içinde tanımlanmış olan problemler

- Kuruluştaki ana harcamaların neler olduğu

- En yüksek maliyetli fonksiyonların belirlenmesi

- Gelişmeye açık olan fonksiyonların belirlenmesi

- Kuruluşu pazardaki rakiplerinden ayıran en önemli etkiye sahip fonksiyonların belirlenmesi

- Veri toplama metodunu oluşturmak

Benchmarking çalışmalarının başarısı büyük ölçüde ekip çalışmasının etkinliğine bağlıdır. Ekipteki kişilerin niteliği projenin önemini yansıtmaktadır (Yıdız ve Ardıç, 1997: 256). Gönüllülük bu tür çalışmaların başarılı olmasını sağlayan en önemli faktördür. Ekip üyelerinin süreci gönüllü olarak yürütmeleri sürecin kalitesini arttıracaktır. Kamu kurumlarında kamu görevlilerine bu tür görevlerin verilmesi çoğu zaman personel tarafından gereksiz bir iş olarak nitelendirilebilir. Bu durum sürecin sağlıklı bir şekilde yürütülmesini engelleyecektir. Takım üyelerinin belediyelerde Strateji Genel Müdürlüğü bünyesinde çalışanlar arasından seçilmesi sürecin takibi açısından düzen sağlayacaktır.

Benchmarking takımının oluşturulmasından sonra benchmarking yapılacak olan alana göre alanında en iyiler araştırılarak kıyaslama ortağı belirlenir. Bu aşamada yerel yönetimler tarafından benchmarking ortağı olarak diğer kamu kurum ve kuruluşları ya da sektörünün en iyisi özel sektör işletmeleri tercih edilebilir. Yerel yönetimler açısından ortağın belirlenmesinde; Mahalli İdareler Genel Müdürlüğü, Kalkınma Bakanlığı, İçişleri Bakanlığı ve Kal-der verilerinden faydalanılabilir. Aynı zamanda profesyonel ve kurumsallaşmış işletmeler ile kalite ödülü gibi özel ödül almış kurum ve kuruluşların çalışmalarının takip edilmesi de ortak belirlenmesinde kolaylık sağlayacaktır.

\subsubsection{Analiz Aşaması}

Bu aşamada bilgi kaynağı olarak çalışanlardan, yöneticilerden, mesleki kuruluşlardan, yayınlardan ve yıllık raporlardan yararlanılabilir. Deneyimler kişisel görüşmelerin en iyi bilgi kaynağı olduğunu göstermektedir. Veri toplamada kullanılacak yöntemin seçimi de önem taşımaktadır. Bunlar; telefon görüşmeleri, ziyaretler, anketler, yayınlar, arşiv araştırmaları şeklinde olabilir. Bu yöntemlerden hangilerinin kullanılacağı zaman ve maddi sınırlamalara tecrübeye ve bilgi toplama felsefesine göre belirlenebilir (Sorularla Kıyaslama, 2004: 24). Diğer yöntemlere göre yüz yüze görüşme metodu benchmarking yapılan konuyu yakından inceleme fırsatı sunarken, diğer kuruluşun kültürü ve yönetim tarzı konusunda da bilgi sahibi olunmasını sağlar. Bu bakımdan kaynak durumuna göre benchmarking ekibinin gerçekleştireceği ziyaretler daha verimli sonuçlar alınmasını sağlayabilir.

Benchmarking takımı kıyaslama ortağı seçim kriterlerine göre ikincil araştırma bilgilerini toplar. Veri toplama aşamasında soru listeleri oluşturulması üst yönetimin tecrübelerinden faydalanmak ve verilerin analizi açısından önem taşır (Kocabaş, 2004: 6). Bilgi kaynağı olarak çalışanlardan, yöneticilerden, mesleki kuruluşlardan, yayınlardan ve yıllık raporlardan yararlanılabilir (Bedük, 2002: 43). Yerel yönetimler bu aşamada kendi iç kaynaklarından yararlanabileceği gibi şayet kıyaslama ortağı farklı bir yerel yönetim birimi olacaksa Mahalli İdareler Genel Müdürlüğü, Kalkınma Bakanlığı ve İçişleri Bakanlığı gibi kurum ve kuruluşların verilerinden de faydalanılabilir.

Analiz aşamasında, en iyi uygulamalar ve şirketin kendi işletme süreçleri arasındaki açıklar tanımlanır ve analiz edilir. İşletmeler aynı zamanda var olan açıkları kapatmak için bu açıkların sebeplerini de belirlemelidirler. Benchmarking analizi, en iyi örgütlerinkine nispetle bir örgütün mevcut durumunu değerler ve büyük fırsatlar, tehditler, güçlü ve zayıf yönler hakkında firmaya bilgi vermeyle sonuçlanır. Böyle çabalar projenin gelecek performans seviyelerinin başarılabilmesine ve iyileştirilebilecek faaliyetlerin keşfedilmesine yardım eder (Tikici vd., 2004: 107-108). Veri analizi aşamasında, toplanan veriler analiz edilerek işletmenin sınıfının en iyileri ile arasındaki farklar saptanır. Bu aşamada ortaya çıkabilecek en önemli sorun, toplanan verilerin birbiriyle uyumlu olmama ihtimalidir. Örneğin bir maliyet verisi söz konusu ise, bu veriler her iki tarafta ayrı ayrı hesaplama sistemine dayandırılarak elde edilmiş olabilir. Bu tür olumsuzlukları ortadan kaldırabilmek için, farklı formlarda toplanan içsel ve dışsal veriler, aynı birimlerle ifade edilen değerlere dönüştürülmelidir (Erdem, 2006: 87). $\mathrm{Bu}$ aşamada benchmarking diğer diğer bir yerel yönetim birimiyle yapılıyorsa özellikle vatandaş memnuniyet düzeyi, kaynakların etkin kullanımı, altyapı çalışmaları gibi hizmet konularında karşılaştırma yapılabilir. Elde edilen sonuçlar aynı zamanda üst yönetim tarafından performans değerlendirme aracı olarak kullanılabilir.

\subsubsection{Uygulama Aşaması}

Benchmarking uygulamasını hayata geçirmeden önce belirlenen hedeflere ulaşmak için hangi eylemlerin, hangi sırada, kim tarafından, hangi zaman diliminde yapılması gerektiğini içeren bir uygulama planı hazırlanmalıdır. Bu planda, uygulamanın mali boyutu da ele alınır. Uygulama planı hazırlandıktan sonra, sonuçları görmek ve hedeflere ulaşııp ulaşılamadığını tespit etmek için bir uygulama raporu hazırlanır. Uygulama raporunun hazırlanmasında, tespitlerin güvenilir olması açısından, benchmarking sürecince müşteriler ile ilişkiler kurulup onların memnuniyet düzeyleri ölçülmeli ve bu ölçümler hazırlanan raporda kullanılmalıdır. Benchmarking uygulamaları için hazırlanan uygulama planı ve raporda standartlaşma olgusuna 
önem verilmesi, benchmarking uygulamalarının etkin bir şekilde gerçekleşmesini ve benchmarking temelli bir yönetim anlayışının süreklilik kazanmasını sağlayabilir (Topaloğlu ve Kaya, 2008: 43). Benchmarking çalışmalarının istenilen sonuçlara ulaşıp ulaşmadığı sürekli kontrol edilmeli, eksik noktalar gözden geçirilerek iyileştirilmelidir. Bunun sağlanabilmesi için bir kontrol listesi geliştirilebilir. Buna göre olumlu ve olumsuz yönler belirlenerek gerekli düzeltmeler yapılabilir.

Hazırlanacak olan kontrol listesi aşağıda belirtilen hususları içerir (Özer, 1999: 77):

- Ölçümler belirlendi mi?

- Benchmarking sonuçları aktarıldı mı?

- Üst yönetimin sahiplenmesi gerçekleştirildi mi?

- Bir hareket planı tasarlandı ve uygulandı mı?

- İstenen sonuçlara ulaşıldı mı?

\subsubsection{Olgunluk Aşaması}

Benchmarking başarıya ulaştığı takdirde kuruluşun yeni benchmarking fırsatlarının belirlenmesi çalışmalarına başlanabilir. Bu aşamada gerçekleştirilecek faaliyetler şunlardır (Kocabaş, 2004: 8);

- Performans farklılığını giderecek ve hatta rakiplerden daha iyi performans çıkaracak hedefler konması

- Süreç iyileştirme çalışmalarının kuruluş kültürüne ve örgüt yapısına uydurulması

- Önerilerin desteklenmesi ve değişikliklere sahip çıkılması

- Benchmarking projesinin sonuçlarının takdir edilmesi

Benchmarking uygulamaları, sürekli olarak ölçüm ve değerlendirmeyi içerir. Değerlendirmenin yanında uygulama aşamasında da uyarlamalara yardım etmesi açısından "geri besleme" unsurunun da sisteme dahil edilmesi gerekir. Performans beklenen seviyede değilse uygulama ve düzenlemeler yapılmalıdır. Benchmarkingin başarıya ulaşabilmesi için üst yönetimin performans göstergelerindeki gelişmeleri yakından izlemesi ve belirli aralıklarla yeniden değerlendirmeler yapması gerekmektedir. Üstünlük sağlandığı zaman "olgunluk" durumuna gelinmiş demektir. Bu aşamada benchmarking yönetim tarzı olarak süreklilik kazanmıştır (Özer, 1999: 77-79).

\section{SONUÇ}

Benchmarking, işletmelerin sürekli değişen dışsal faktörleri göz önünde bulundurup öğrenerek gelişmenin farkındalığıyla kendini diğer işletmelerle karşılaştırdığı ve yönetsel süreçleri gözden geçirip kendisini başarıya taşıyacak yenilikleri keşfetmesi sürecidir. Sürükleyici bir güç olan benchmarking, değişimi gerçekleştirip yönetmeyi ve bu sayede de sürekli gelişmeyi ve kaliteyi olanaklı kılmaktadır. İşletme literatüründe "benchmarking" olarak kullanılan bu yönetim süreci kamu yönetiminde genellikle "hizmet karşılaştırması" olarak kullanılmaktadır. Özel sektörden beklenen kar amacı kamu sektöründe fayda amacı olarak değerlendirilmektedir. İnsanların istek, talep ve beklentilerinin giderek artması özel ve kamu sektörü ayrımı yapmadan iş sahiplerini ve kurum yöneticilerini yeniliğe, kaliteye ve değişime zorlamaktadır. Bu durum kamu yönetiminde de "Yeni Kamu Yönetimi" anlayışının oluşmasına sebep olmuştur. 1980'lerden itibaren kamusal kesim ile özel kesim arasındaki etkileşim artmıştır. Bu nedenle müşteri tercihlerine duyarlı kalite odaklı yönetimin kamu kesiminde uygulanmasına yönelik istek ve eğilimler giderek yaygınlık kazanmıştır.

Kamu kurumlarında kurumsal kültürü oluşturmanın temelinde kanunlar yer almaktadır. Görev ve yetkiler kanunlarla belirlenmektedir. Yöneticilerin, yönetim ve çalışanların da çalışma anlayışına göre bir takım uygulama farklılıkları oluşsa da verilen hizmet aynıdır. Hizmetin kalitesini arttırmak "Yeni Kamu Yönetimi” anlayışı ve bu anlayışın sağladığı "Toplam Kalite Yönetimi, Öğrenen Organizasyon, Dış Kaynaklardan Yararlanma, Süreç Yenileme, Benchmarking ve Personel Güçlendirme" gibi modern işletme yönetim yaklaşımları ile mümkün olabilmektedir.

Bu çalışmada benchmarkingin literatürdeki yeri incelenmiş olup "Yeni Kamu Yönetimi" anlayışı içerisinde nasıl yer bulduğuna değinildikten sonra bir işletme yönetim yaklaşımı olan "Benchmarking"i uygulayan ve olumlu sonuçlar alan Nilüfer Belediyesinin çalışması incelenmiş ve benchmarkingin yerel yönetimler açısından uygulanabilirliği değerlendirilmiştir. Literatürde yer alan çalışmalar incelendiğinde benchmarking uygulama sürecinin belli bir sıralamayı izlediği görülmektedir. Bu durum dikkate alınarak yerel yönetimler açısından kullanılabilecek dört aşama ve dokuz adımdan oluşan bir süreç değerlendirilmesi yapılmıştır.

Yapılan araştırma sonucunda Nilüfer Belediyesinin benchmarking çalışmasını "Kalite Yönetim Sistemi" içerisinde yürüttüğü görülmektedir. 2000 yılında "Kalite Yönetim Bürosunun" kurulması ile çalışmalarına başlayan belediye, çalışmalarını Strateji Geliştirme Genel Müdürlüğü'nün alt bünyesinde oluşturulan bir ekiple yürütmektedir. "Fonksiyonel Benchmaking” türünü kullanan Nilüfer Belediyesi gerek başka belediye gerekse farklı sektörlerdeki firmaların faaliyetlerini inceleyerek çeşitli uygulama örneklerinden faydalanabilmektedir. 2003 yılından itibaren Benchmarking çalışmalarını EFQM Mükemmellik Modelinin bir gereği olarak uygulayan belediye; "Stratejik Benchmarking” yöntemini kullanarak benchmarking çalışmasını 
stratejik planlama süreci içerisine almıştır. Benchmarking ortaklarının belirlenmesinde mükemmellik modelini uygulayan Belediye, modelin uygulanmasında uluslararası ve ulusal alanda başarı sağlamış ve iyi uygulamaları olan kurumları seçtiğini belirtmektedir. Çalışmada Nilüfer Belediyesinin "Bosch" ve "Tarsus Belediyesi "ne yapmış olduğu kıyaslama ziyaretleri sorucevap yöntemiyle değerlendirilmiştir. Bosh kıyaslama ziyaretinde veri karşılaştırması yapılmasa da ziyaret sonrasında Bosch'un PESTEL Analizi uygulamasından etkilenerek Belediyede bu uygulama başlatılmıştır. Tarsus Belediyesi kıyaslama ziyaretinde ise, vatandaş algıları ve performans sonuçları, çalışan algıları ve performans göstergeleri, toplumla ilgili performans göstergeleri ve iş sonuçlarından bazıları (gelirin gidere oranı, stratejik hedeflerin gerçekleşme oranı, tahsil edilen verginin tahakkuk edilen vergiye oranı gibi) konularda karşılaştırma yapıımıştır. Aynı zamanda yapılan bu ziyaretin sonunda QPR Portalı satın alınmıştır. Bu portalın 2013 yılı Avrupa Kalite Ödül Sürecinde Modelin 5. Kriterinin (Süreçler) puan artışına önemli katkıda bulunduğu ifade edilmiştir.

Genel olarak çalışmada ele alınan sürece göre benchmarking modeli yerel yönetimler açısından değerlendirildiğinde aşağıdaki sonuçlara ulaşımıştır;

- Yerel yönetimlerde yöneticiler seçimle iş başına gelmektedirler. Üst yönetimin liderliği olmadan sürecin başlaması ve bu süreçten fayda sağlanması mümkün olmayacaktır. Dolayısıyla planlama aşamasında sürecin başlatılabilmesi için üst yönetimin benchmarking yöntemini kullanmaya karar vermesi gerekmektedir. Bu aşamada önemli olan bir diğer husus da yönetici değişikliği durumunda sistemin sürekliliğinin sağlanabilmesi için üst yönetimin kurumsal sahiplenmeyi de sağlamış olması gerekmektedir.

- Benchmarking yapacak olan yerel yönetimlerin başarılı sonuçlara ulaşabilmeleri için öncelikle stratejik planlama süreçlerini doğru bir şekilde yürütmeleri gerekmektedir. Stratejik planlama süreci yerel yönetimler açısından yasal bir zorunluluktan öte kaliteli hizmet vermek adına içerisinde doğru ve ölçülebilir hedefleri barındıran bir süreç olarak algılanmalı ve yönetilmelidir. Bu aşamada kurumun güçlü ve zayıf yönleri ile fırsat ve tehditlerini ortaya koyacak olan SWOT Analizi, karşılaştırma grubunun tespit edilmesi açısından belirleyici bir faktör oluşturacaktır.

- Benchmarking bir an önce bitirilecek hızlı bir eylem değil, uzun soluklu ve sabır gerektiren bir süreç olarak değerlendirilmelidir. Dolayısıyla süreci yönetecek olan ekibin bu özelliklere sahip bireylerden seçilmesi gerekmektedir. Kamu görevlileri açısından bu durum değerlendirildiğinde bu görevi üstlenecek olan personelde; gönüllü olmak, vatandaş ihtiyaçlarını anlamış, esnek düşünebilen ve hareket edebilen, iletişim kurabilme yeteneğine sahip olma gibi özelliklerin bulunması ekip başarısını arttıracaktır.

- Benchmarking ekibinin oluşturulmasından sonra kıyaslama yapılacak olan alana göre sınıfının en iyileri araştırılarak benchmarking ortağı tespit edilir. Bu aşamada yerel yönetimler tarafından benchmarking ortağı olarak diğer kamu kurum ve kuruluşları ya da sektörünün en iyisi özel sektör işletmeleri tercih edilebilir. Yerel yönetimler açısından ortağın belirlenmesinde; Mali İdareler Genel Müdürlüğü, Kalkınma Bakanlığı, İçişleri Bakanlığı ve Kalder verilerinden faydalanılabilir. Aynı zamanda profesyonel ve kurumsallaşmış işletmeler ile kalite ödülü gibi özel ödül almış kurum ve kuruluşların çalışmalarının takip edilmesi de ortak belirlenmesinde kolaylık sağlayacaktır.

- Veri toplama ve analiz aşamasında benchmarking ortağının ne kadar iyi olduğu, niçin daha iyi olduğu, onlardan nelerin öğrenilebileceği ve öğrenilenlerin nasıl uygulanabileceği değerlendirilir. Yazışma, anket, yüz yüze görüşme ile veri toplanmaya çalışıır. Verilerin anlaşılabilir olması için tablo, grafik vb. araçlardan yararlanılabilir. Mevcut veriler ortağın verileri ile karşılaştırılır ve bu verilere göre karşılaştırmalar yapılır.

- Uygulama aşamasında süreç başarıyla yürütüldüyse kurum bu aşamada çalışma ile bir değişim yaşayacağının farkına vararak başka işletmelerden öğrenilen farklı uygulamaları kendi örgütsel yapı ve kültürüne uyarlamaya çalışacaktır. Elde edilen sonuçlar üst yönetimle paylaşılarak ilgili birim temsilcileri sürece dahil edilerek sonuçlar değerlendirilmelidir. Eğer başarıya ulaşıldıysa kuruluşun yeni benchmarking fırsatlarının belirlenmesi çalışmalarına başlanmalıdır.

Başarılı olmuş en iyi uygulamaları incelemenin ve onlardan öğrenmenin önemini fark eden yerel yönetimler, diğer belediyeleri ya da sektör dışından en iyi uygulamaları kendi iş süreçleri ile kıyaslayarak kuruluşların gelişimine ve hizmet kalitelerinin artmasına katkı sağlayabilirler. Yasal düzenlemelerle yetki ve sorumlulukları her geçen gün daha da artan yerel yönetimlerin vatandaşa daha kaliteli hizmet etme istekleri ve kaynaklarını etkin kullanma zorunlulukları onları yeni yönetim tekniklerini öğrenmeye ve uygulamaya itmektedir. Yeni kamu yönetimi anlayışı da işletme yönetiminin benimsemiş olduğu bir takım prensipleri ortaya koymaktadır. Benchmarking de bu prensipler içinde kamu kurumlarınca son yıllarda benimsenen ve uygulanan yöntemlerden biri olmuştur. Benchmarking, işletmelerin sürekli olarak değişen dişsal faktörleri göz önünde bulundurup öğrenerek, gelişmenin farkındalığıyla kendisini diğer işletmelerle karşılaştırıp yönetsel süreçlerini gözden geçirmesiyle kendisini kalite ve başarıya götürecek olan yenilikleri keşfetmesini sağlayan bir süreç olarak tanımlandığında bu yöntemin yerel yönetimler açısından da kullanılabilmesi mümkün görülmektedir. 


\section{KAYNAKLAR}

Bayraktar, B. B. ve Yıldız, A. K. (2007). Kurumsal bilginin stratejik planlama sürecinde kullanılması: Bir ilçe belediyesi örneği. Bilgi Dünyası, Cilt 8, Sayı 2, s. 280-296.

Bedük, A. (2002). Benchmarking. Ankara: Nobel Yayınları.

Bumin, B. ve Erkutlu, H. (2002). Toplam kalite yönetimi ve kıyaslama (benchmarking) ilişkileri. Gazi Üniversitesi İktisadi ve İdari Bilimler Dergisi, Cilt 1, s. 83-100.

Camp, R. C. (1989). Benchmarking - The search for industry best practices that lead to superior performance. Milwaukee, WI: ASQC Quality Press.

Dattakumar, R. ve Jagadeesh, R. (2003). A Review of literature on benchmarking. Benchmarking: An International Journal, Cilt 10, s. 176209.

Demirel, E. T.,Yatkın, A., Düşükcan, M., Derin, N., Çakınberk, A. ve Güven, M. (2013). Seçmen görüşlerine göre belediye hizmet kalitesi: bir ölçek geliştirme çalışması. Çağdaş Yerel Yönetimler, Cilt 22, Sayı 3, s. 31-52.

Demirkaya, Y. (2008). Yerel yönetimlerde bir politika transfer aracı olarak benchmarking. “iş,Güç” Endüstri İlişkileri ve İnsan Kaynakları Dergisi, Cilt 10, Sayı 1, s. 160-179.

Drew, S.A.W. (1997). From knowledge to action: the impact of benchmarking on organizational performance. Long Range Planning, Cilt 30, s. 427-441.

Erdem, B. (2006). İşletmelerde yeni bir yönetim yaklaşımı: kıyaslama (benchmarking) (yazınsal bir inceleme). Balıkesir Üniversitesi Sosyal Bilimler Dergisi, Cilt 9, Sayı 15, s. 65-98.

Eren, V. (2002). Kamu yönetiminde bir rekabet aracı olarak hizmet karşılaştırması yenilik ve başarı geliştirme. Amme İdaresi Dergisi, Cilt 35, Sayı 2, s. 61-75.

Ensari, H. (2004). 21. Yüzyıl okulları için kıyaslayarak öğrenme. İstanbul: Sistem Yayıncılık.

Fong, S. W., Cheng, E. W. L. ve Danny, C.K. H. (1998). Benchmarking: a general reading for management practitioners. Management Decision, Cilt 36, Sayı 6, s. 407-418.

Jetmarová, B. (2011). Comparison of best practice benchmarking models. problems of management in the 21st Century. 6 de Setembro de 2011, s. 76-84.

Kleine B. (1994). Benchmarking for continuous performance improvement: Tactics for success. Total Quality Environmental Management, Spring.

Kocabaş, ì. (2004). Eğitim yönetiminde kıyaslama (benchmarking) yöntemi. Eğitim ve Bilim Dergisi, Cilt 29, Sayı 132, s. 3-9.

Seymen Aytemiz, O. ve Bolat, T. (2002). Örgütsel öğrenme ve kıyaslama (benchmarking) tekniğinin bir örgütsel öğrenme aracı olarak kullanılması. Bursa: Ezgi Kitabevi.

Siverbo, S. (2014). The implementation and use of benchmarking in local government: a case study of the translation of a management accounting innovation. Financial Accountability \& Management, Cilt 30, Sayı 2, s.121-149.

Sorularla Kıyaslama. (2004). İşletme yönetiminde yeni eğilimler dizisi. İstanbul Ticaret Odası, Yayın No: 2004-27.

Tektaş, A. ve Tosun, E. Ö. (2010). Yiyecek içecek endüstrisinde uluslararası performans kıyaslaması. Süleyman Demirel Üniversitesi İktisadi ve İdari Bilimler Fakültesi Dergisi, Cilt 15, Sayı 1, s. 29-44.

Tikici, M. (2004). Toplam kalite yönetim tekniği olarak kıyaslama. Ankara: Nobel Yayın Dağıtım.

Topaloğlu, C. ve Kaya, U. (2008). Benchmarking (Kıyaslama): turizm işletmeleri açısından kuramsal bir değerlendirme. Ekonomik ve Sosyal Araştırmalar Dergisi, Cilt 4, Sayı 1, s. 23-50

Vaziri H.K. (1992). Using competitive benchmarking to set goals. Quality Progress, Cilt 8, s. 1-5.

Watson, G. H. (2007). Strategic benchmarking reloaded with six sigma. Published by John Wiley \& Sons, Inc., Hoboken, New Jersey.

Yıldız, G. ve Ardıç, K. (1997). Benchmarking'te bilgiye ulaşmada ahlak sorunu. Siyasette ve Yönetimde Etik Sempozyumu, Adapazarı, 24-26 Aralık 1997, s. 256

Zairi, M. (1994). Benchmarking: The best tool for measuring competitiveness. Benchmarking for Quality Management \& Technology, Cilt 1, Sayı 1, s. 11-24

Zairi, M. ve Al-Mashari, M. (2005). The Role of benchmarking in best practice management and knowledge sharing. Journal of Computer Information Systems, s. 14-31.

www.mevzuat.gov.tr 